\title{
ANALISIS PENGARUH KINERJA KEUANGAN DAN VARIABEL MAKROEKONOMI TERHADAP RETURN SAHAM SUBSEKTOR PERKEBUNAN
}

\author{
Faizul Mubarok, Hermanto Siregar, Nunung Nuryartono \\ Institut Pertanian Bogor \\ faizul @yahoo.com; hermanto@mma.ipb.ac.id; nuryantono@ipb.ac.id
}

\begin{abstract}
EVA and MVA are used to indicate the creation of value in an investment. Arbitrage Pricing Theory (APT) explained that macroeconomic variables have a systematic effect on return. The aim of this study is to analyze and to measure the effect of financial performance and macroeconomic variables on the stock return of estate plantation subsector at Indonesia Stock Exchange. Data are processed by using panel data, analysis which consist of six companies which are listed on the estate plantation sub-sector and using quarterly data from 2007 to 2013. By using the Pooled Least Square (PLS) the result show that the variables of MVA, oil, inflation, interest rate and crisis have significant effects on the stock return of estate plantation sub-sector while the variables of MVA and the world oil price do not have significant effect on the stock return of estate plantation sub-sector.
\end{abstract}

Keywords: Financial Performance; Macroeconomy; Plantation; Panel Data

\begin{abstract}
Abstrak
EVA dan MVA digunakan untuk menunjukkan penciptaan nilai dalam investasi. Arbitrage Pricing Theory (APT) menjelaskan bahwa variabel ekonomi makro memiliki efek sistematis pada return saham. Tujuan dari penelitian ini adalah untuk menganalisis dan mengukur pengaruh kinerja keuangan dan variabel makroekonomi terhadap return saham sub-sektor perkebunan di Bursa Efek Indonesia. Data diolah dengan menggunakan data panel, analisis yang terdiri dari enam perusahaan yang terdaftar di sub-sektor perkebunan dan menggunakan data kuartal dari tahun 2007 hingga 2013. Dengan menggunakan Pooled Least Square (PLS) hasil menunjukkan bahwa variabel MVA, minyak, inflasi, suku bunga dan krisis memiliki pengaruh yang signifikan terhadap return saham sub-sektor perkebunan sedangkan variabel MVA dan harga minyak dunia tidak memiliki pengaruh yang signifikan terhadap return saham sub-sektor perkebunan.
\end{abstract}

Kata Kunci: Kinerja Keuangan; Ekonomi Makro; Perkebunan; Data Panel

Diterima: 22 Mei 2014; Direvisi: 8 Juli 2014; Disetujui: 15 Juli 2014 


\section{PENDAHULUAN}

Sektor pertanian merupakan salah satu sektor penggerak perekonomian yang memiliki peranan penting dalam pertumbuhan perekonomian di Indonesia. Salah satunya dalam bentuk Produk Domestik Bruto (PDB). Kontribusi PDB sektor pertanian Indonesia pada tahun 2011 mencapai Rp. 315.037,- triliun sehingga menempati urutan ketiga dalam struktur PDB Indonesia. Seiring dengan laju pertumbuhan ekonomi khususnya di sektor pertanian, peluang usaha sektor pertanian masih cukup besar.

Beberapa indikator yang menunjukkan masih besarnya peluang usaha sektor pertanian (Oktavio, 2013) adalah pertama, ketersediaan dan dukungan sumber daya alam (lahan, air dan iklim) serta sumber daya manusia yang masih besar. Kedua, permintaan dunia terhadap produksi pertanian Indonesia yang terus meningkat karena negara ini merupakan produsen utama beberapa komoditas pertanian yang dibutuhkan dunia, yaitu minyak sawit, karet, kakao, kopi, lada, panili dan kayu manis. Ketiga, naiknya harga pangan dunia, juga memberikan peluang lebih besar kepada pelaku usaha untuk memperoleh keuntungan yang lebih tinggi dan berkelanjutan. Keempat, pemerintah berkomitmen untuk menciptakan iklim investasi yang kondusif melalui peraturan yang lebih berpihak kepada para petani ataupun pelaku usaha di bidang pertanian. Mengingat masih tingginya kontribusi sektor pertanian dalam perekonomian nasional, sudah semestinya tidak mengabaikan potensi sektor pertanian, terutama subsektor perkebunan. Trend volume ekspor komoditas perkebunan dari tahun 2007 hingga 2011 cenderung mengalami peningkatan.

Beberapa produk perkebunan di Indonesia juga sangat mendunia, seperti kelapa sawit, karet dan kelapa merupakan komoditas perkebunan penyumbang ekspor tertinggi di Indonesia. Komoditas perkebunan ini dari tahun 2007 hingga 2011 memiliki kontribusi penyumbang nilai ekspor yang selalu meningkat tiap tahunnya. Pada 2011, ketiga komoditas perkebunan ini memberikan kontribusi terhadap devisa negara dengan volume sebesar 20,9 juta ton untuk kelapa sawit, karet memberikan sumbangan devisa volume mencapai 2,6 juta ton dan kelapa mencapai 1,04 ton. Padahal, di tengah meluapnya arus impor barang dari luar negeri, komoditas perkebunan masih menjadi komoditi unggulan di kancah internasional. Trend ekspor perkebunan yang terus meningkat ini, memberikan gambaran bahwa produk perkebunan Indonesia telah mampu bersaing di pasar internasional sehingga mampu memberikan kontribusi yang sangat berarti dalam devisa perdagangan. 
Gambar 1. Kontribusi subsektor perkebunan terhadap volume (ton) dan nilai (US\$000) ekspor impor sektor pertanian

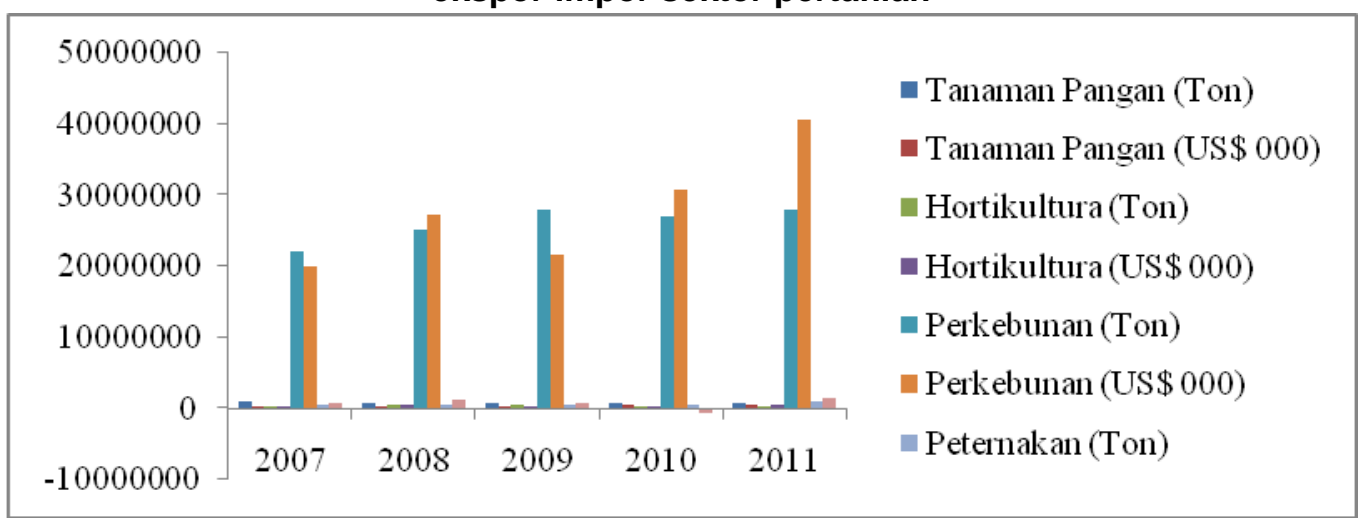

Sumber: BPS, 2012 diolah

Simanjuntak (2013), menyatakan bahwa saat ini Indonesia menjadi negara utama penghasil beberapa produk perkebunan, seperti kelapa sawit, karet, kelapa, kopi, kakao, lada. Indonesia dikenal sebagai negara utama penghasil CPO dengan produksi sebesar 27,25 juta ton pada 2012 atau senilai US $\$ 20,78$ miliar. Selain itu, Indonesia juga dikenal sebagai negara terbesar dunia kedua penghasil kopra, terbesar ketiga penghasil kopi, terbesar kedua penghasil karet, terbesar ketiga penghasil kakao dan terbesar kedua penghasil lada.

Gambar 2. Volume (ton) ekspor perkebunan Indonesia

\begin{tabular}{rl|l|l|}
25000000 \\
20000000 \\
15000000 \\
10000000 \\
5000000
\end{tabular}

Sumber: BPS, 2012 diolah

Begitu pula dalam segi nilai, tahun 2008 sampai 2009 harga beberapa komoditas perkebunan unggulan Indonesia mengalami penurunan sehingga ekspor kelapa sawit, karet, kopi Indonesia pada tahun 2009 menurun dibandingkan tahun 2008. Nilai ekspor kelapa sawit tahun 2009 menurun sebesar 16.9 persen dibandingkan 2008, nilai ekspor karet alam Indonesia tahun 2009 juga menurun sebesar 43.9 persen. Kondisi yang sama dialami oleh nilai ekspor kopi yang menurun sebesar 16.4 persen. Namun, pada 
periode tahun 2009 sampai 2010 kinerja ekspor komoditas perkebunan terus naik seiring dengan peningkatan harga.

Gambar 3. Nilai (US\$000) ekspor perkebunan Indonesia

\begin{tabular}{rl|l|l|}
25000000 \\
20000000 \\
$15000000-$
\end{tabular}

Sumber: BPS, 2012 diolah

Walaupun dari segi volume maupun nilai komoditas perkebunan mengalami peningkatan. Namun, tahun 2006 sampai 2012 pergerakan indeks sektor pertanian dan Indeks Harga Saham Gabungan (IHSG) mengalami pergerakan yang berfluktuatif. Indeks sektor pertanian dan IHSG mengalami peningkatan 2006 sampai 2007, sebesar 126.09 persen dan 52.08 persen. Pada tahun 2008, indeks saham sektor pertanian dan IHSG mengalami penurunan sebesar 66.65 persen dan 50.64 persen. Hal ini terjadi karena dampak krisis global tahun 2008. Pasca krisis tahun 2008, IHSG mengalami peningkatan sampai 2012. Sedangkan kondisi sektor pertanian hanya mengalami peningkatan pada tahun 2009 sampai 2010. Pada tahun 2011 dan 2012, sektor pertanian mengalami penurunan sebesar 6.05 persen dan 3.87 persen.

\section{Gambar 4. Perkembangan IHSG dan indeks saham sektor pertanian}



Sumber: BEI 2012, diolah

Salah satu upaya untuk meningkatan potensi dan menggerakan kinerja keuangan adalah melalui investasi (Saeed dan Akhter, 2012). Pengukuran kinerja keuangan 
sangat bermanfaat bagi investor dalam mengambil keputusan untuk berinvestasi. Selama ini, pengukuran kinerja keuangan umumnya dilakukan dengan menganalisa laporan keuangan. Pengukuran ini memiliki kelemahan utama, yaitu mengabaikan adanya biaya modal, sehingga sulit untuk mengetahui apakah suatu perusahaan telah berhasil menciptakan nilai atau tidak (Lehn dan Makhija, 1997). Untuk mengatasi hal tersebut, saat ini telah dikembangkan konsep baru, yaitu Economic Value Added (EVA) dan Market Value Added (MVA).

EVA dan MVA merupakan indikator tentang adanya penciptaan nilai dari suatu investasi. Adapun tujuannya untuk mendorong aktivitas perusahaan yang cenderung mampu menambah nilai dan manghapuskan aktivitas perusahaan yang justru merusak nilai tambah tersebut. Pada metode EVA, hal yang ditekankan adalah bagaimana kemampuan perusahaan dalam mengelola modal yang diinvestasikan oleh pemegang saham. Sedangkan metode MVA lebih menekankan pada kemampuan perusahaan dalam meningkatkan kekayaan (wealth) investor melalui peningkatan nilai perusahaan di pasar modal. Disamping itu, kondisi makro yang baik tentunya akan mendorong investasi di pasar saham. Fenomena krisis global beberapa tahun yang lalu telah berdampak pada pasar keuangan dalam negeri. Investor yang hendak menanamkan sahamnya tentu akan melihat variabel tersebut sebagai pertimbangan dalam keputusan membeli atau menjual saham. Bodie et al. (2008) menyatakan bahwa ada beberapa variabel makroekonomi untuk menilai kondisi ekonomi makro, diantaranya Gross Domestic Product (GDP), employment, inflation, interest rate, exchange rates, current account dan budget defisit.

Berdasarkan uraian diatas, maka tujuan penelitian ini adalah: pertama, menganalisis dan mengukur pengaruh kinerja keuangan perusahaan emiten terhadap return saham subsektor perkebunan pada Bursa Efek Indonesia; Kedua, menganalisis dan mengukur pengaruh variabel makroekonomi terhadap return saham subsektor perkebunan pada Bursa Efek Indonesia.

\section{METODE}

Data yang digunakan dalam penelitian ini seluruhnya menggunakan data sekunder periode September 2007 hingga Juni 2013, meliputi laporan keuangan triwulanan perusahaan, data harga closing saham perusahaan, nilai tukar, harga minyak dunia, tingkat suku bunga dan inflasi yang diperoleh dari Bursa Efek Indonesia (BEI), yahoo 
finance, pacific exchange rate service, index mundi, Bank Indonesia (BI) serta studi kepustakaan lainnya.

Tabel 1. Langkah-langkah perhitungan EVA

\begin{tabular}{|c|c|c|}
\hline No & Langkah-langkah & Keterangan \\
\hline \multirow[t]{4}{*}{1} & Net Operating Profit After Taxes (NOPAT) & \\
\hline & a. Earning Before Interest and Taxes (EBIT) & Laporan Laba Rugi \\
\hline & b. Taxes & Laporan Laba Rugi \\
\hline & c. NOPAT & $(1 a) \times[1-(1 b)]$ \\
\hline \multirow[t]{5}{*}{2} & Cost of Debt & \\
\hline & a. Beban bunga & Laporan laba rugi \\
\hline & b. Hutang jangka panjang & Neraca \\
\hline & c. Tarif pajak penghasilan & Laporan laba rugi \\
\hline & d. Cost of debt & {$[(2 a):(2 b)] \times[1-(2 c)]$} \\
\hline \multirow[t]{5}{*}{3} & Cost of Equity & \\
\hline & a. Tingkat hasil bebas resiko & $\mathrm{SBI}$ \\
\hline & b. Tingkat hasil pasar & IHSG \\
\hline & c. Beta & Diketahui \\
\hline & d. Cost of equity & $(3 a)+\{[(3 b)-(3 a)] \times(3 c)\}$ \\
\hline \multirow[t]{5}{*}{4} & Struktur Modal & \\
\hline & a. Total hutang jangka panjang & Neraca \\
\hline & b. Total modal & Neraca \\
\hline & c. Komposisi hutang & $(4 a):[(4 a)+(4 b)]$ \\
\hline & d. Komposisi modal & $(4 b):[(4 a)+(4 b)]$ \\
\hline 5 & Weight Average Capital of Cost (WACC) & {$[(2 d) \times(4 c)]+[(3 d)+(4 d)]$} \\
\hline \multirow[t]{4}{*}{6} & Modal yang Diinvestasikan & \\
\hline & a. Total hutang jangka panjang & Neraca \\
\hline & b. Total modal & Neraca \\
\hline & c. Modal yang Diinvestasikan & $(6 a)+(6 b)$ \\
\hline 7 & Economic Value Added (EVA) & $(1 c)-[(5) \times(6 c)]$ \\
\hline
\end{tabular}

Sumber: Keown et al., 2000

Data return saham subsektor perkebunan yang di maksud adalah harga closing saham $i$ periode $t$ dikurangi harga closing saham $i$ periode $t-1$ dibagi dengan harga closing saham i periode t-1. Economic Value Added (EVA) merupakan ukuran keberhasilan manajemen perusahaan dalam meningkatkan nilai tambah bagi perusahaan dengan cara menghitung selisih laba operasi setelah pajak dengan biaya modal setelah pajak dikalikan dengan modal operasi. Langkah perhitungan EVA dapat dilihat pada Tabel 1. Market Value Added (MVA) merupakan selisih antara nilai pasar perusahaan (termasuk ekuitas dan hutang) dan modal keseluruhan yang diinvestasikan dalam perusahaan. Nilai pasar perusahaan, yaitu jumlah nilai pasar dari semua tuntutan modal terhadap perusahaan oleh pasar modal pada tanggal tertentu (jumlah nilai pasar dari hutang dan 
ekuitas). Data nilai tukar mata uang yang dimaksud adalah nilai tukar perusahaan $i$ periode $t$ dikurangi nilai tukar perusahaan $i$ periode $t-1$ dibagi dengan nilai tukar perusahaan $i$ periode $t-1$. Data harga minyak dunia yang dimaksud adalah harga minyak perusahaan $i$ periode $t$ dikurangi harga minyak perusahaan $i$ periode $t-1$ dibagi dengan harga minyak perusahaan $i$ periode $t-1$. Data inflasi yang dimaksud adalah Indeks Harga Konsumen (IHK) perusahaan $i$ periode $t$ dikurangi Indeks Harga Konsumen (IHK) perusahaan $i$ periode $t-1$ dibagi dengan Indeks Harga Konsumen (IHK) perusahaan $i$ periode $t-1$. Data tingkat suku bunga yang dimaksud adalah tingkat suku bunga perusahaan $i$ periode $t$ dikurangi tingkat suku bunga perusahaan $i$ periode $t-1$.

Pengolahan data dalam penelitan ini menggunakan model data panel. Model ini adaptasi dari model penelitian Ismail (2006), serta Khan, Hira, Zaheer (2011) yang merupakan model data panel adalah sebagai berikut:

$$
\begin{aligned}
\text { Rit }=\alpha & +\beta_{1} \text { EVA }_{i t}+\beta_{2} \text { MVA }_{i t}+\beta_{3} \text { US }_{i t}+\beta_{4} \text { OIL }_{i t}+\beta_{5} \text { INF }_{i t}+\beta_{6} \text { BIRATE }_{i t} \\
& +\beta_{7} \text { KRISIS }_{i t}+e_{i t}
\end{aligned}
$$

\section{Dimana:}

EVA $_{\text {it }} \quad$ : perubahan EVA saham i bulan ke-t

MVA $_{\text {it }} \quad$ : perubahan MVA saham i bulan ke-t

US\$ : : perubahan nilai tukar rupiah terhadap dolar saham i bulan ke-t

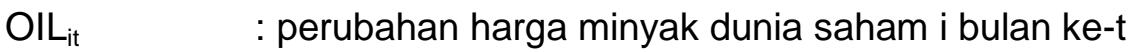

$\mathrm{INF}_{\text {it }} \quad$ : perubahan laju inflasi saham i bulan ke-t

BIRATE $_{\text {it }} \quad$ : perubahan tingkat suku bunga saham i bulan $\mathrm{t}$

Krisis $_{\text {it }} \quad$ : variabel dummy krisis ekonomo saham i bulan ke-t

Hipotesis yang akan dicoba pada penelitian ini adalah :

$\mathrm{H}_{0}$ : Kinerja keuangan (EVA dan MVA) dan variabel makroekonomi (nilai tukar, harga minyak dunia, inflasi, tingkat suku bunga dan krisis) tidak berpengaruh terhadap return saham subsektor perkebunan pada BEI

$\mathrm{H}_{1}$ : Kinerja keuangan (EVA dan MVA) dan variabel makroekonomi (nilai tukar, harga minyak dunia, inflasi, tingkat suku bunga dan krisis) berpengaruh terhadap return saham subsektor perkebunan pada BEI.

Pemilihan model terbaik dilakukan secara statistik dengan regresi berganda menggunakan data panel, terdapat tiga pendekatan perhitungan model regresi data 
panel (Juanda dan Junaidi, 2012), yaitu: metode pooled least square, metode efek tetap, dan model efek acak. Dalam menentukan metode yang paling tepat untuk mengestimasi parameter regresi data panel, maka perlu dilakukan pengujian berdasarkan pertimbangan statistik, yaitu: pertama, Chow Test atau uji F statistik yang bertujuan untuk memilih apakah lebih baik menggunakan model PLS atau fixed effect. Hipotesis yang digunakan yaitu $\mathrm{H}_{0}=$ model PLS dan $\mathrm{H}_{1}=$ model fixed effect. Dasar penolakan terhadap $\mathrm{H}_{0}$, jika nilai hasil pengujian chow statistik lebih besar dari F-tabel atau jika nilai probabilitas uji lebih kecil dari nilai $\alpha$; Kedua, Hausman test yang bertujuan untuk memilih apakah lebih baik menggunakan model random effect atau fixed effect. Hipotesis yang digunakan yaitu $\mathrm{H}_{0}=$ model random effect dan $\mathrm{H}_{1}=$ model fixed effect. Dasar penolakan terhadap $\mathrm{H}_{0}$, jika hasil pengujian chow statistik lebih besar dari nilai chi-square table atau jika nilai probabilitas uji lebih kecil dari nilai $\alpha$; Ketiga, Lagrange Multiplier merupakan pengujian statistik yang bertujuan untuk memilih apakah lebih baik menggunakan model PLS atau random effect. Hipotesis yang digunakan yaitu $\mathrm{H}_{0}=$ model PLS dan $\mathrm{H}_{1}=$ model random effect. Dasar penolakan terhadap $\mathrm{H}_{0}$, jika nilai hasil pengujian Lagrange Multiplier lebih besar dari nilai chisquare table. Setelah menentukan metode terbaik, selanjutnya dilakukan uji asumsi klasik meliputi uji normalitas, multikolinearitas, heteroskedastisitas, autokorelasi dan stasioner yang secara rinci dapat dijelaskan sebagai berikut.

\section{HASIL DAN PEMBAHASAN}

Salah satu asumsi pada pengujian parametrik adalah mensyaratkan data harus terdistribusi normal. Model regresi yang baik adalah yang memiliki distribusi data normal/mendekati normal. Pada dasarnya, uji normalitas hanya digunakan jika jumlah observasi adalah kurang dari 30. Jika jumlah observasi lebih dari 30, maka tidak perlu dilakukan uji normalitas. Sebab distribusi sampling error term telah medekati normal (Ajija et al., 2011). Pada penelitian ini, data cross section yang digunakan berjumlah 6 , sedangkan data time series berjumlah 24 , sehingga total observasi yang diamati berjumlah 144. Berdasarkan jumlah observasi yang diamati, maka data dalam penelitian ini dapat dikatakan bahwa error term terdistribusi normal. Multikolinearitas muncul jika diantara variabel independen memiliki korelasi yang tinggi sehingga sulit untuk memisahkan efek suatu variabel independen terhadap variabel dependen dari efek variabel lainnya. Pada model regresi yang baik, antar variabel independen seharusnya tidak terjadi kolerasi. 
Tabel 2. Hasil pengujian multikolinearitas

\begin{tabular}{ccccccccc}
\hline & RETURN & \multicolumn{1}{c}{ EVA } & \multicolumn{1}{c}{ MVA } & KURS & \multicolumn{1}{c}{ OIL } & INFLASI & BIRATE & \multicolumn{1}{c}{ KRISIS } \\
\hline RETURN & 1.000 & -0.030 & 0.161 & -0.486 & 0.618 & -0.306 & -0.425 & -0.024 \\
EVA & -0.030 & 1.000 & 0.140 & 0.391 & -0.258 & -0.276 & -0.172 & 0.393 \\
MVA & 0.161 & 0.140 & 1.000 & -0.070 & 0.105 & 0.059 & 0.066 & -0.020 \\
KURS & -0.486 & 0.391 & -0.070 & 1.000 & -0.686 & 0.150 & 0.036 & 0.108 \\
OIL & 0.618 & -0.258 & 0.105 & -0.686 & 1.000 & -0.108 & -0.326 & 0.006 \\
INFLASI & -0.306 & -0.276 & 0.059 & 0.150 & -0.108 & 1.000 & 0.567 & -0.490 \\
BIRATE & -0.425 & -0.172 & 0.066 & 0.036 & -0.326 & 0.567 & 1.000 & -0.154 \\
KRISIS & -0.024 & 0.393 & -0.020 & 0.108 & 0.006 & -0.490 & -0.154 & 1.000 \\
\hline
\end{tabular}

Ada atau tidaknya multikolineritas dapat diketahui dari koefisien korelasi variabel bebas. Jika koefisien korelasi diantara masing-masing variabel bebas lebih besar dari 0.8, maka terjadi multikolinearitas (Ajija et al., 2011). Berdasarkan Tabel 2, hasil pengujian multikolinearitas dapat dilihat dari nilai korelasi semua variabel kurang dari 0,8 .

Model regresi yang baik adalah regresi yang bebas dari autokorelasi. Autokorelasi ini umumnya terjadi pada data time series. Model regresi yang baik adalah yang bebas autokorelasi. Pengujian yang bisa digunakan untuk mengetahui kemungkinan terjadinya autokorelasi adalah dengan pengujian menggunakan metode Lagrange Multiplier (LM) atau The Breusch Godfrey Test dengan hipotesis, yaitu $\mathrm{H}_{0}$ tidak ada Autokorelasi dan $\mathrm{H}_{1}$ ada Autokorelasi.

Jika terdapat $\mathrm{p}$-value $O b s^{\star} R$-Squared yang lebih kecil dari a maka data tersebut ada Autokorelasi, sedangkan jika terdapat $p$-value $O b s^{*} R$-Squared yang lebih besar dari $\alpha$ maka data tersebut tidak ada Autokorelasi. Dari pengujian yang dilakukan menggunakan pengujian metode Lagrange Multiplier (LM) yang terdapat pada Tebel 3, dengan a sebesar 0,1 atau selang kepercayaan 90 persen menunjukkan bahwa nilai $p$ value lebih besar dari a sehingga hipotesis yang berlaku terima $\mathrm{H}_{0}$ dan tolak $\mathrm{H}_{1}$. Jadi, dapat disimpulkan bahwa model pada penelitian ini tidak mengandung autokorelasi atau bebas autokorelasi.

Tabel 3. Hasil pengujian Autokorelasi

\begin{tabular}{llll}
\hline F-statistic & 1.422667 & Prob. F(12,124) & 0.1642 \\
Obs*R-squared & 17.42634 & Prob. Chi-Square(12) & 0.1343 \\
\hline
\end{tabular}

Pada pengujian heteroskedastisitas dalam penelitian ini diperlukan suatu alat pengujian untuk mendeteksi adanya heteroskedastisitas. Alat pengujian tersebut adalah pengujian menggunakan White Heteroscedastcity. Pengujian ada atau tidaknya 
heterokedastisitas menggunakan hipotesis, yaitu $\mathrm{H}_{0}$ tidak ada heterokedastisitas dan $\mathrm{H}_{1}$ ada heterokedastisitas. Jika terdapat $p$-value $O b s^{*} R$-Squared yang lebih kecil dari $\alpha$ maka data tersebut ada heteroskedastisitas, sedangkan jika terdapat $p$-value Obs ${ }^{*}$ Squared yang lebih besar dari a maka data tersebut tidak ada heteroskedastisitas. Dari pengujian yang dilakukan menggunakan pengujian White Heteroscedastcity yang terdapat pada Tabel 4, dengan a sebesar 0,1 atau selang kepercayaan 90 persen menunjukkan bahwa nilai $p$-value lebih besar dari a sehingga hipotesis yang berlaku terima $\mathrm{H}_{0}$ dan tolak $\mathrm{H}_{1}$. Jadi, dapat disimpulkan bahwa model pada penelitian ini tidak mengandung heterokedastisitas.

Tabel 4. Hasil pengujian heterokedastisitas

\begin{tabular}{llll}
\hline F-statistic & 0.086800 & Prob. F $(1,141)$ & 0.7687 \\
Obs*R-squared & 0.087977 & Prob. Chi-Square(1) & 0.7668 \\
\hline
\end{tabular}

Data time series yang baik adalah data yang stasioner. Data time series umumnya mengandung Unit Root, sehingga menyebabkan suatu data tidak stasioner pada level tertentu. Pengujian stasioneritas pada penelitain ini menggunakan pengujian Augmented Dickey Fuller (ADF). Adapun pengujian ada atau tidaknya Unit Root menggunakan hipotesis, yaitu $\mathrm{H}_{0}$ ada Unit Root dan $\mathrm{H}_{1}$ tidak ada Unit Root.

Jika terdapat nilai $A D F$ Test Statistics yang lebih kecil dari nilai ktitisnya maka tidak ada root atau stasioner, sedangkan jika terdapat nilai ADF Test Statistics yang lebih besar dari nilai ktitisnya maka ada root atau tidak stasioner. Dari pengujian yang dilakukan menggunakan pengujian ADF Test Statistics yang terdapat pada Tabel 5, menunjukkan bahwa nilai ADF Test Statistics lebih kecil dari nilai ktitisnya, sehingga hipotesis yang berlaku tolak $\mathrm{H}_{0}$ dan terima $\mathrm{H}_{1}$. Jadi, dapat disimpulkan bahwa data pada penelitian ini sudah stasioner.

Tabel 5. Hasil pengujian stasioneritas

\begin{tabular}{lccc}
\hline \multicolumn{2}{l}{ Augmented Dickey-Fuller test statistic } & t-Statistic & Prob. $^{*}$ \\
Test critical values: & & -7.643897 & 0.0000 \\
& 5\% level & -3.435816 & \\
& $10 \%$ level & -2.863842 & \\
\hline
\end{tabular}

*MacKinnon (1996) one-sided p-values.

Penelitian ini menggunakan data panel, yaitu gabungan dari data time series (antar waktu) dan cross section (antar individu) memiliki tiga pendekatan dalam pemilihan model terbaik, yakni pendekatan kuadrat terkecil (pooled least square), pendekatan 
efek tetap (fixed effect) dan pendekatan efek acak (random effect). Hasil pengujian yang dilakukan meliputi uji Chow, uji Hausman dan uji Breusch-Pagan LM menghasilkan bahwa berdasarkan hasil uji Chow dimana nilai $P(0,21)>0,1$ yang berarti terima $\mathrm{H}_{0}$, maka pada penelitian ini menggunakan pendekatan Pooled Least Square (PLS) dengan hasil sebagai berikut.

Tabel 5. Hasil pengolahan pooled least square

\begin{tabular}{crrrr}
\hline Variable & \multicolumn{1}{c}{ Coefficient } & \multicolumn{1}{c}{ Std. Error } & \multicolumn{1}{c}{-Statistic } & \multicolumn{1}{c}{ Prob. } \\
\hline EVA & $1.53 \mathrm{E}-08$ & $9.41 \mathrm{E}-09$ & 1.622363 & 0.1070 \\
MVA & $3.01 \mathrm{E}-09$ & $1.79 \mathrm{E}-09$ & 1.681696 & $0.0949^{*}$ \\
US $\$$ & -0.886507 & 0.538984 & -1.644774 & 0.1023 \\
OIL & 0.664760 & 0.147827 & 4.496887 & $0.0000^{*}$ \\
INFLASI & -0.248526 & 0.123892 & -2.005982 & $0.0468^{*}$ \\
BIRATE & -12.24271 & 6.083161 & -2.012557 & $0.0461^{*}$ \\
KRISIS & -0.105627 & 0.046209 & -2.285833 & $0.0238^{*}$ \\
C & 0.048395 & 0.037876 & 1.277714 & 0.2035 \\
R-squared & 0.509616 & Prob(F-statistic) & 0.000000 \\
\hline
\end{tabular}


12,24 BIRATE $_{i t}-0,1 \mathrm{KRISIS}_{\text {it }}+\mathrm{e}_{\text {it }}$

Nilai $\mathrm{R}^{2}$ ( $R$-squared) merupakan besaran yang memberikan informasi goodness of fit dari persamaan, yaitu memberikan proporsi atau persentase kekuatan pengaruh variabel yang menjelaskan (EVA, MVA, nilai tukar, harga minyak dunia, inflasi, tingkat suku bunga dan krisis) secara simultan terhadap variasi dari variabel dependen (R). Koefisien determinasi $\left(R^{2}\right)$ digunakan untuk mengukur seberapa jauh kemampuan model dalam menerangkan variasi variabel dependen. Nilai $R^{2}$ sendiri akan cenderung semakin besar bila jumlah variabel dan jumlah data observasinya semakin banyak. Hasil pengolahan pada penelitian ini, menjelaskan bahwa dari model memiliki nilai $\mathrm{R}^{2}$ sebesar 50,96 persen yang artinya bahwa variabel-variabel independen di atas dapat menjelaskan pengaruhnya terhadap return saham subsektor perkebunan, sedangkan sisanya 49,04 persen dijelaskan oleh faktor lain yang tidak dimasukkan ke dalam model ini.

Uji F dilakukan untuk mengetahui pengaruh semua variabel independen yang terdapat di dalam model secara bersama-sama (simultan) terhadap variabel dependennya. Hasil pengolahan data penelitian didapatkan bahwa probabilitas F-statistik memiliki pengaruh signifikan pada 0.000000 , lebih kecil dari nilai a sebesar 10 persen. Dari hasil ini berarti 
tolak $\mathrm{H}_{0}$ dan terima $\mathrm{H}_{1}$, mengindikasikan bahwa secara keseluruhan semua variabel independen yang meliputi EVA, MVA, nilai tukar, harga minyak dunia, inflasi, tingkat suku bunga dan krisis memiliki pengaruh terhadap variabel dependennya, yaitu return saham subsektor perkebunan.

Pengujian terhadap koefisien regeresi secara parsial dilakukan dengan uji t. Pengujian ini dilakukan untuk mengetahui signifikansi peran secara parsial antara variabel independen terhadap variabel dependen dengan mengasumsikan bahwa variabel independen lain dianggap konstan. Dengan tingkat signifikan sebesar 90 persen, nilai $t$ hitung dari masing-masing koefisien regresi kemudian dibandingkan dengan a sebesar 10 persen, sehingga terdapat 5 koefisien yang memiliki nilai kurang dari 10 persen, yakni MVA, harga minyak dunia, inflasi, tingkat suku bunga dan krisis yang berarti memiliki pengaruh signifikan terhadap return saham subsektor perkebunan. Sedangkan 2 koefisien lainnya, MVA dan nilai tukar memiliki nilai lebih dari 10 persen yang berarti tidak berpengaruh terhadap return saham subsektor perkebunan.

\section{Interpretasi Model}

\section{Pengaruh EVA terhadap Return Saham Subsektor Perkebunan}

Variabel EVA memiliki probabilitas 0,107 dengan a sebesar 10 persen serta koefisien 1,53E-08. Hasil ini menunjukkan bahwa variabel EVA tidak berpengaruh terhadap return saham subsektor perkebunan. Pada dasarnya, EVA merupakan salah satu alat pengukur keberhasilan manajemen dalam meningkatkan nilai tambah bagi perusahaan. Perusahaan yang memiliki nilai EVA yang tinggi cenderung dapat lebih menarik investor untuk berinvestasi di suatu perusahaan, karena semakin tinggi EVA maka semakin tinggi pula nilai perusahaan tersebut. Semakin tinggi nilai perusahaan maka investor yang berinvestasi melalui saham pada perusahaan juga akan bertambah, sehingga akan menaikkan harga saham yang pada akhirnya akan meningkatkan return saham. EVA yang positif berarti perusahaan memperoleh laba karena tingkat pengembalian melebihi biaya modalnya, sehingga return saham juga akan semakin tinggi. Hal ini menunjukkan hubungan positif antara EVA terhadap return yang diperoleh para investor.

Hasil ini sejalan dengan penelitian yang dilakukan oleh Usman (2004) yang menyebutkan bahwa analisis kinerja keuangan menggunakan EVA tidak berpengaruh terhadap return saham pada 37 perusahaan di Bursa Efek Jakarta (BEJ). Begitu pula yang dilakukan oleh Ismail (2006) di pasar modal Inggris. Namun, Chen dan Dodd 
(1997), Garvey dan Milbourn (2000), dan Christanty (2009) mendapatkan hasil bahwa EVA secara signifikan berpengaruh terhadap return saham.

\section{Pengaruh MVA terhadap Return Saham Subsektor Perkebunan}

Variabel MVA memiliki probabilitas 0,09 dengan a sebesar 10 persen serta koefisien 3,01E-09. Hasil ini menunjukkan bahwa variabel MVA secara signifikan berpengaruh positif terhadap return saham sub-sektor perkebunan. MVA merupakan ukuran kekayaan yang mengukur nilai perusahaan dari waktu ke waktu. MVA mencerminkan ekspektasi investor terhadap perusahaan dalam menciptakan kekayaan di masa mendatang. MVA positif menunjukkan bahwa saham perusahaan tersebut dinilai oleh investor lebih besar dari pada nilai buku per lembarnya sehingga harga saham akan semakin tinggi. Jadi, kekayaan pemilik perusahaan akan bertambah bila MVA bertambah melalui meningkatnya dividen dari meningkatnya harga saham. Semakin tinggi dividen, maka return saham yang diperoleh investor juga akan meningkat. Hal ini menunjukkan hubungan positif antara MVA terhadap return yang diperoleh para investor.

Hasil ini sejalan dengan penelitian yang dilakukan oleh Mundaryatiningsih (2006) mendapatkan hasil bahwa MVA secara signifikan berpengaruh positif terhadap return saham. Namun, Usman (2004) yang menyebutkan bahwa analisis kinerja keuangan menggunakan MVA tidak berpengaruh terhadap return saham pada 37 perusahaan di Bursa Efek Jakarta (BEJ). Begitu pula yang dilakukan oleh Dewanto (2005) pada sektor pertambangan di Bursa Efek Jakarta (BEJ).

\section{Pengaruh Nilai Tukar terhadap Return Saham Subsektor Perkebunan}

Variabel nilai tukar rupiah terhadap dolar AS (US\$) memiliki probabilitas 0,102 dengan a sebesar 10 persen serta koefisien $-0,88$. Hasil ini menunjukkan bahwa variabel nilai tukar tidak berpengaruh terhadap return saham subsektor perkebunan. Ketika nilai rupiah terdepresiasi maka return saham akan mengalami penurunan. Pelemahan nilai kurs rupiah menunjukkan situasi fundamental perekonomian Indonesia dalam kondisi suram. Ketika prospek perekonomian suram, maka investor cenderung melepaskan saham-saham yang dimilikinya untuk menghindari resiko. Aksi jual saham ini tentunya akan mendorong penurunan return saham perusahaan.

Hasil penelitian ini mendukung penelitian yang telah dilakukan oleh Abdalla dan Murinde (1997) yang menyatakan bahwa nilai tukar tidak berpengaruh terhadap harga saham di Filipina. Sedangkan Jayadin (2012) dalam penelitiannya menyatakan bahwa 
nilai tukar secara signifikan berpengaruh positif terhadap return saham sektor energi dan pertambangan di Bursa Efek Indonesia (BEI). Begitu pula penelitian yang dilakukan oleh Hondroyiannis dan Papapetrou (2001), bahwa nilai tukar secara signifikan berpengaruh terhadap harga saham di pasar modal Yunani dan Khan et al (2011) juga mendapatkan hasil serupa, bahwa nilai tukar secara signifikan berpengaruh negatif terhadap return saham di Pakistan.

\section{Pengaruh Harga Minyak Dunia terhadap Return Saham Subsektor Perkebunan}

Variabel harga minyak dunia (OIL) memiliki probabilitas 0,00 dengan a sebesar 10 persen serta koefisien 0,66. Hal ini menunjukkan bahwa variabel harga minyak dunia secara signifikan berpengaruh positif terhadap return saham subsektor perkebunan. Pada dasarnya, meningkatnya harga minyak dunia ini dilatarbelakangi oleh meningkatnya konsumsi dan pemintaan minyak dunia. Meningkatnya konsumsi dan permintaan terhadap minyak dunia ini disebabkan oleh pertumbuhan ekonomi dunia. Karena kenaikan harga minyak didasarkan pada meningkatnya konsumsi dan permintaan, maka kenaikan harga minyak sendiri baik secara langsung maupun tidak langsung mendorong kenaikan harga saham dan pada akhirnya return saham juga akan meningkat. Hasil ini terjadi karena seluruh perusahaan perusahaan subsektor perkebunan yang diteliti merupakan perusahaan kelapa sawit (crude palm oil/CPO) dan pengekspor CPO, sehingga berakibat ketika harga minyak dunia mengalami kenaikan maka harga CPO yang diekspor akan mengalami kenaikan dan membuat para investor banyak menanamkan sahamnya untuk mendapatkan keuntungan dari saham tersebut.

Hasil ini sejalan dengan penelitian yang dilakukan oleh Jayadin (2012) pada sektor energi dan pertambangan, bahwa harga minyak dunia secara signifikan berpengaruh positif terhadap return saham. Begitu pula penelitian yang dilakukan oleh Kilian dan Park (2007) bahwa kenaikan harga minyak akibat meningkatnya permintaan akan mendorong kenaikan harga saham dan sesuai dengan penelitian yang dilakukan oleh Witjaksono (2010) yang menyatakan bahwa harga minyak dunia secara signifikan berpengaruh positif terhadap harga saham pada sektor manufaktur. Namun, berbeda dengan penelitian yang dilakukan oleh Hammoudeh dan Choi (2006), yang menyatakan bahwa Western Texas Intermediate (WTI) tidak memberikan pengaruh terhadap pasar saham di negara Gulf Cooperation Council's (Bahrain, Kuwait, Oman, Saudi Arabia dan UAE). 


\section{Pengaruh Inflasi terhadap Return Saham Subsektor Perkebunan}

Variabel inflasi memiliki probabilitas 0,04 dengan a sebesar 10 persen serta koefisien 0,24 . Hasil ini menunjukkan bahwa variabel inflasi secara signifikan berpengaruh negatif terhadap return saham subsektor perkebunan. Hasil ini juga menunjukkan bahwa inflasi merupakan salah satu faktor yang mempengaruhi investasi pada saham subsektor perkebunan. Adanya pengaruh inflasi terhadap saham sub-sektor perkebunan menandakan inflasi sangat terkait dengan penurunan kemampuan daya beli, baik individu maupun perusahaan. Ketika inflasi mengalami kenaikan, maka efeknya adalah biaya operasional perusahaan menjadi membengkak. Akibatnya, laba bersih perusahaan akan turun dan pada akhirnya return saham mengalami penurunan.

Hasil penelitian ini sejalan dengan penelitian yang dilakukan Skendra (2005) bahwa inflasi secara signifikan berpengaruh terhadap return saham blue chip. Thobarry (2009) mendapatkan hasil yang sama pada sektor properti, bahwa inflasi secara signifikan berpengaruh negatif terhadap return saham.

\section{Pengaruh Suku Bunga terhadap Return Saham Subsektor Perkebunan}

Variabel $\mathrm{BI}$ rate memiliki probabilitas 0,04 dengan a sebesar 10 persen serta koefisien 12,24. Hasil ini menunjukkan bahwa variabel $\mathrm{BI}$ rate secara signifikan berpengaruh negatif terhadap return saham subsektor perkebunan. Pada dasarnya, tingkat suku bunga dan saham merupakan dua hal yang saling bertolak belakang. Hasil ini menggambarkan bahwa kenaikan tingkat suku bunga akan mengakibatkan menurunnya return saham subsektor perkebunan dan sebaliknya penurunan tingkat suku bunga akan mengakibatkan kenaikan return saham subsektor perkebunan. Dalam menghadapi kenaikan suku bunga, para pemegang saham cenderung akan menjual sahamnya sampai tingkat suku bunga kembali pada tingkat yang dianggap normal.

Hasil ini sejalan dengan penelitian yang dilakukan oleh Hondroyiannis dan Papapetrou (2001), bahwa tingkat suku bunga secara signifikan berpengaruh terhadap pasar saham di Yunani. Begitu pula peneliatian yang dilakukan oleh Khan et al (2011), bahwa tingkat suku bunga secara signifikan berpengaruh negatif terhadap return saham di Pakistan. Namun, Jayadin (2012) pada sektor energi dan pertambangan di Bursa Efek Indonesia (BEI), hasil yang didapat menjelaskan bahwa tingkat suku bunga secara signifikan berpengaruh positif terhadap return saham energi dan pertambangan. 


\section{Pengaruh Krisis terhadap Return Saham Subsektor Perkebunan}

Variabel krisis memiliki probabilitas 0,023 dengan $\alpha$ sebesar 10 persen serta koefisien $-0,1$. Hasil ini menunjukkan bahwa variabel krisis secara signifikan berpengaruh negatif terhadap return saham. Krisis global pada tahun 2008 menimbulkan permasalahan likuiditas perusahaan-perusahaan keuangan di Amerika Serikat (AS). Disamping itu, saat terjadi krisis di Amerika, diikuti dengan penarikan dana aset keuangan di pasar modal, sehingga menurunkan nilai pasar saham, yang pada akhirnya menurunkan return saham. Perpindahan modal dan aset secara dominan terjadi pada perusahaan-perusahaan subsektor perkebunan, dikarenakan perusahaan perusahaan tersebut memiliki kapitalisasi modal yang besar (Andati, 2012).

Hasil ini sejalan dengan penelitian yang dilakukan oleh Raz et al. (2012) yang menyatakan bahwa krisis finansial global pada tahun 2008 telah memberikan dampak buruk bagi perekonomian di Asia timur. Hal ini menunjukkan bahwa harga saham subsektor perkebunan cenderung mengalami penurunan saat terjadinya krisis. Hasil ini berbeda dengan penelitian yang dilakukan oleh Chongvilaivan (2010) yang menyatakan bahwa pada tingkat sektoral, sektor pertanian menunjukkan lebih tahan terhadap krisis dibandingkan dengan sektor manufaktur ataupun jasa.

\section{SIMPULAN}

Berdasarkan hasil dan pembahasan, dapat disimpulkan bahwa pengukuran kinerja keuangan perusahaan emiten menggunakan metode EVA dan MVA pada perusahaan emiten subsektor perkebunan Berdasarkan perhitungan hasil uji secara parsial (uji t), variabel EVA tidak berpengaruh terhadap return saham subsektor perkebunan. Perusahaan yang memiliki nilai EVA yang tinggi cenderung dapat lebih menarik investor untuk berinvestasi di suatu perusahaan, karena semakin tinggi EVA maka semakin tinggi pula nilai perusahaan tersebut sehingga akan menaikkan return saham perusahaan. Sedangkan variabel MVA secara signifikan berpengaruh positif terhadap return saham subsektor perkebunan. MVA positif menunjukkan bahwa saham perusahaan tersebut dinilai oleh investor lebih besar dari pada nilai buku per lembarnya sehingga return saham akan semakin tinggi.

Adapun variabel makroekonomi, harga minyak dunia secara signifikan berpengaruh positif terhadap return saham subsektor perkebunan. Perusahaan subsektor perkebunan yang diteliti merupakan perusahaan kelapa sawit dan 
pengekspor CPO, sehingga berakibat harga CPO akan mengalami kenaikan yang pada akhirnya akan menaikkan return saham seiring dengan kenaikan harga minyak dunia. Variabel inflasi secara signifikan berpengaruh negatif terhadap return saham subsektor perkebunan. Ketika inflasi mengalami kenaikan, maka efeknya adalah biaya operasional perusahaan menjadi membengkak. Akibatnya, laba bersih perusahaan akan turun sehingga berdampak pada menurunnya return saham. Variabel tingkat suku bunga secara signifikan berpengaruh negatif terhadap return saham subsektor perkebunan. Dalam menghadapi kenaikan suku bunga, para pemegang saham cenderung akan menjual sahamnya sampai tingkat suku bunga kembali pada tingkat yang dianggap normal sehingga akan berdampak pada menurunnya return saham.

Variabel dummy krisis secara signifikan berpengaruh negatif terhadap return saham subsektor perkebunan. Krisis global pada tahun 2008 menimbulkan permasalahan likuiditas perusahaan-perusahaan keuangan di Amerika Serikat (AS). Hal tersebut menyebabkan AS mengalami resesi yang mempengaruhi kemampuan daya beli masyarakat AS. Dari sisi perdagangan internasional, penurunan daya beli tersebut akan ikut mempengaruhi permintaan impor AS yang berdampak pada permintaan ekspor dunia sehingga mengurangi tingkat ekspor perusahaan yang pada akhirnya akan menurunkan return saham perusahaan. Sedangkan variabel nilai tukar tidak berpengaruh terhadap return saham subsektor perkebunan. Ketika nilai rupiah terdepresiasi maka investor cenderung melepaskan saham-saham yang dimilikinya untuk menghindari resiko. Aksi jual saham ini tentunya akan mendorong penurunan return saham perusahaan.

Rekomendasi yang dapat dirumuskan dari hasil dan pembahasan pada penelitian ini adalah bagi perusahaan yang ingin menghasilkan nilai MVA yang optimal, perlu melakukan perubahan orientasi seluruh manajemen agar lebih mengedepankan pada penciptaan nilai tambah perusahaan. Salah satunya dengan peningkatan dan pengendalian pengawasan terhadap semua kegiatan perusahaan secara intensif agar kondisi perusahaan berorientasi pada penciptaan nilai tambah. Peningkatan dan pengendalian pengawasan perusahaan dapat dilakukan dengan beberapa penyesuaian pada neraca dan laporan laba rugi perusahaan. Disamping itu, selain mempertimbangkan kinerja keuangan, investor perlu juga mempertimbangkan variabel makro ekonomi yang berpengaruh terhadap return saham subsektor perkebunan 
karena variabel tersebut akan mempengaruhi kinerja perusahaan yang pada akhirnya akan mempengaruhi return saham perusahaan.

\section{PUSTAKA ACUAN}

Abdalla ISA, M. V. 1997. Exchage Rate and Stock Price Interactions in Emerging Financial Markets: Evidence on India, Korea, Pakistan and the Philippines. Journal Applied Financial Economics. 7 (1), pp. 2535.

Andati T. 2012. Pengaruh Faktor-Faktor Makro-Mikro terhadap Pertumbuhan Investasi Sektoral dalam Era Liberalisasi Keuangan : Analisis Q-Tobin. Disertasi Tidak Dipublikasikan. Bogor: Institut Pertanian Bogor.

Bodie, Z, et.al. 2008. Essential Of Investments $7^{\text {th }}$ Edition. New York (US) : The McGraw-Hill.

Chen S, D.J.L. 1997. Economic Value Added (EVA) : An Empirical Examination of New Corporate Measure. Journal of Managerial Issues. 9(3), pp. 318-333.

Chongvilaivan, A. 2010. Global Financial Crisis and growth prospects in Asia-Pacific: A sectoral analysis. paper presented at The 26th Conference of the American Committee for Asian Economic Studies.

Christanty, M. 2009. Pengaruh Faktor Fundamental dan Economic Value Added (EVA) terhadap Return Saham (Studi Kasus LQ 45 Periode 20032007). Tesis Tidak Dipublikasikan. Semarang: Sekolah Pascasarjana Universitas Diponegoro.

Dewanto H. 2005. Analisis Pengaruh Economic Value Added, Market Value Added, Residual Income dan Cash Flow Operation Terhadap Imbal Hasil Saham Sektor Pertambangan di BEJ 1995-2004. Tesis Tidak Dipublikasikan. Depok: Universitas Indonesia.

Garvey, GT and Milbourn TT. 2000. EVA versus Earningss : Does It Matter Which Is More Highly Correlated with Return?. Journal of Accounting Research. 38 (1), pp. 209-245.

Hammoudeh, S and K. Choi. 2006. Behavior of GCC Stock Markets and Impacts of US Oil and Financial Markets. Journal Research in International Business and Finance. 20 (1), pp. 2244.

Hondroyiannis, G and E. Papapetrou. 2001. Macroeconomic influences on the stock market. Journal Of Economic and Finance. Vol. 25 (1), pp. 33-49.

Ismail, A. 2006. Is Economic Value Added More Associated with Stock Return than Accounting Earning? The UK Evidence. Internasional Journal of Managerial Finance. Vol. 2 (4), pp. 343-353. 
Juanda, B dan Junaidi. 2012. Ekonometrika Deret Waktu - Teori dan Aplikasi. Bogor: IPB Press.

Jayadin. 2012. Analisis Pengaruh Makro Ekonomi, IHSG dan Harga Minyak Dunia Terhadap Return Saham Energi dan Pertambangan. Tesis Tidak Dipublikasikan. Bogor: Sekolah Pascasarjana Institut Pertanian Bogor.

Keown, AJ, et.al. 2000. Dasar-Dasar Manajemen Keuangan. Jakarta: Salemba Empat.

Khan, A, et.al. 2011. Impact Of Macro-Economic Factors On Stock Prices. Interdisciplinary Journal Of Contemporary Research In Business. Vol. 3 (1), pp. 472-483.

Lehn K, Makhija A. 1997. Accounting Profits and CEO Turnover ; An Empirical Examination, 1985-1994. Journal of Applied Corporate Finance. 10 (2):90-97.

Mundaryatiningsih, S. 2006. Analisis Pengaruh Kinerja Keuangan Perusahaan Terhadap Kapitalisasi Pasar dan Return Saham Perusahaan Publik di Bursa Efek Jakarta. Tesis Tidak Dipublikasikan. Bandung: Sekolah Pascasarjana Institut Teknologi Bandung.

Oktavio N. 2013. Jalan Panjang Memacu Pertumbuhan Investasi Sektor Pertanian. http://setkab.go.id/artikel-8545-.html. Diakses 21 Juni 2013.

Raz, AF, et.al. 2012. Krisis Keuangan Global dan Pertumbuhan Ekonomi : Analisa dari Perekonomian Asia Timur. Jakarta: Buletin Ekonomi Moneter dan Perbankan.

Saeed, S and N. Akhter. 2012. Impact of Macroeconomic Factors on Banking Index in Pakistan. Interdisciplinary Journal of Contemporary Research In Business. 4 (12), pp. 1200-1218.

Skendra, Z. 2005. Analisis Pengaruh Inflasi, Nilai Tukar Rupiah dan bunga Deposito Terhadap Portofolio Optimum Saham-Saham Blue Chips di Bursa Efek Indonesia. Tesis Tidak Dipublikasikan. Bogor: Sekolah Pascasarjana Institut Pertanian Bogor.

Simanjuntak, PL. 2013. Komoditas Perkebunan Telah Menyumbang Perdagangan yang Signifikan Bagi Pertanian. http://www.beritarayaonline.com/2013/08/ komoditas-perkebunan-telah-menyumbang.html\#.Uxg5hs72SOo. Diakses 6 Maret 2014.

Thobarry, AA. 2009. Analisis Pengaruh Nilai Tukar, Suku Bunga, Laju Inflasi dan Pertumbuhan GDP Terhadap Indeks Harga Saham Sektor Properti (Kajian Empiris Pada Bursa Efek Indonesia Periode Pengamatan Tahun 2000-2008). Tesis Tidak Dipublikasikan. Semarang: Sekolah Pascasarjana Universitas Diponegoro.

Usman, Y. 2004. Analisis Pengaruh EVA, MVA dan Kinerja Keuangan Konvensional terhadap Return Saham di Bursa Efek Jakarta. Tesis 
Tidak Dipublikasikan. Semarang: Sekolah Pascasarjana Universitas Diponegoro.

Witjaksono, AA. 2010. Analisis Pengaruh Tingkat Suku Bunga SBI, Harga Minyak Dunia, Harga Emas Dunia, Kurs Rupiah, Indeks Nikkei 225, dan Indeks Dow Jones terhadap IHSG (studi kasus pada IHSG di BEI selama periode 2000-2009). Tesis Tidak Dipublikasikan. Semarang: Sekolah Pascasarjana Universitas Diponegoro. 